\title{
Implementasi dan critical success factor manajemen risiko di instansi Pemerintah
}

\author{
Rifqie Jauhari*; Citra Sukmadilaga; Sri Mulyani \\ Fakultas Ekonomi dan Bisnis, Universitas Padjadjaran \\ *E-mail korespodensi:Rifqie.Jauhari@gmail.com
}

\begin{abstract}
The development of risk management is not only for the private sector, the Ministry of Finance is one of the public sector organizations that has implemented risk management. The purpose of this research is to analyze risk management implementation process and its critical success factors in government agencies, particularly Ministry of Finance. This research uses a qualitative research method with a case study approach. Data collection was carried out by field research and literature study. Data analysis was performed using the Miles \& Huberman data analysis model. The findings indicated the development of risk management in the Ministry of Finance as well as the critical success factors that affects the development of risk management. Of the 8 critical success factors identified, strong management commitment \& leadership as well as risk management knowledge are required by government agencies when implementing risk management. Strengthening management commitment \& leadership as well as risk management knowledge may facilitate government agencies in implementing risk management.
\end{abstract}

Keywords: Risk management, Government agencies, Critical success factor

\begin{abstract}
Abstrak
Perkembangan manajemen risiko tidak hanya untuk sektor swasta saja, salah satu organisasi sektor publik yang telah menerapkan manajemen risiko adalah Kementerian Keuangan. Tujuan dari penelitian ini adalah untuk melihat bagaimana proses implementasi manajemen risiko dan critical success factor di instansi pemerintah khususnya pada Kementerian Keuangan. Penelitian ini menggunakan metode penelitian Kualitatif dengan pendekatan studi kasus. Pengumpulan data dilakukan dengan penelitian lapangan dan studi kepustakaan. Analisis data dilakukan dengan menggunakan model analisis data miles \& Huberman. Hasil penelitian ini adalah diketahui perkembangan manajemen risiko di Kementerian keuangan serta critical success factor yang mempengaruhi perkembangan manajemen risiko tersebut. Dari 8 critical success factor yang teridentifikasi, diperlukan management commitment \& leadership serta risk management knowledge yang kuat bagi instansi pemerintah yang akan menerapkan manajemen risiko. Dengan memperkuat management commitment \& leadership serta risk management knowledge akan memudahkan instansi pemerintah dalam menerapkan manajemen risiko.
\end{abstract}

\section{Kata kunci: Manajemen risiko, Instansi pemerintah, Critical success factor}

\section{PENDAHULUAN}

Dalam pelaksanaan kegiatan usaha dapat dipastikan selalu mengandung suatu risiko. Risiko tersebut tidak mungkin dihilangkan sama sekali, oleh karena itu diperlukan suatu pengendalian terhadap risiko tersebut, dengan melakukan suatu pemetaan terhadap risiko maka risiko tersebut akan dapat dikendalikan. Keberhasilan mengendalikan risiko 
pun dapat meningkatkan keunggulan untuk bersaing baik dalam bersaing dengan perusahaan kompetitor maupun bersaing dalam menghadapi perubahan global yang terjadi (Lark, 2015)

Proses mengendalikan risiko tersebut dikenal dengan istilah Manajemen Risiko. Tujuan dari manajemen risiko ini adalah untuk melindungi organisasi dari kerugian yang akan mungkin timbul. Dalam hal ini peran manajemen dalam mengelola risiko yang dihadapi oleh perusahaannya adalah menerapkan risk appetite dan menetapkan strategi untuk memanfaatkan peluang untuk keuntungan dan pertumbuhan perusahaan sekaligus melindungi perusahaan dari tingkat risiko yang tidak dapat ditanggung oleh perusahaan (Schneider, Sheikh, \& Simione, 2012)

Kementerian keuangan pertama kali menerapkan manajemen risiko dengan mengeluarkan Peraturan Kementerian Keuangan No. 191/PMK.09/2008 Penerapan Manajemen Risiko di Lingkungan Departemen Keuangan. Manajemen risiko pun bertujuan untuk membantu organisasi mencapai tujuannya (Florio \& Leoni, 2017). Demikian halnya dengan Kementerian Keuangan dimana dengan menerapkan manajemen risiko ini akan memperbaiki kinerja organisasi. Hal ini dibuktikan dengan tabel berikut:

Tabel 1. Capaian kinerja kementerian keuangan

\begin{tabular}{lrrr}
\hline & $\mathbf{2 0 1 6}$ & $\mathbf{2 0 1 7}$ & $\mathbf{2 0 1 8}$ \\
\hline Total Indikator Kinerja Utama (IKU) & $\mathbf{2 6}$ & $\mathbf{2 8}$ & $\mathbf{3 3}$ \\
\hline $\begin{array}{l}\text { Persentase IKU yang emenuhi } \\
\text { ekspektasi (Hijau) }\end{array}$ & $77 \%$ & $86 \%$ & $91 \%$ \\
$\begin{array}{l}\text { Persentase IKU yang belum memenuhi } \\
\text { ekspektasi (Kuning) }\end{array}$ & $15 \%$ & $14 \%$ & $6 \%$ \\
$\begin{array}{l}\text { Persentase IKU yang tidak memenuhi } \\
\text { ekspektasi (Merah) }\end{array}$ & $8 \%$ & $0 \%$ & $3 \%$ \\
\hline
\end{tabular}

Data diperoleh dari (Kementerian Keuangan Republik Indonesia, 2016 - 2018) Dari tabel tersebut diatas diketahui bahwa setiap tahun mulai dari tahun 2016 s.d 2018 jumlah Indikator Kinerja Utama atau IKU di Kementerian Keuangan terus meningkat. Meskipun demikian capaian IKU yang memenuhi ekspektasi (Hijau) pun juga meningkat. Demikian pula dengan jumlah IKU yang belum memenuhi ekspektasi (kuning) terus menurun.

Penelitian sebelumnya dilakukan oleh Leung \& Isaacs (2008) penelitian tersebut dilakukan Dewan Riset Nasional Pemerintah Kanada dimana dalam penelitian tersebut menyatakan bahwa Dewan Riset Nasional (National Research Council - NRC) harus mengelola berbagai risiko strategis dan operasional, termasuk yang ada di tingkat proyek, program, dan portofolio. Penelitian lain dilakukan oleh Kapuscinska \& Matejun (2014) penelitian tersebut melihat bagaimana manajemen risiko pada organisasi sektor publik. Dalam penelitian ini menyatakan bahwa kegiatan organisasi sektor publik berkaitan erat dengan risiko yang harus dapat diidentifikasi, dianalisis, dievaluasi, dimonitor dan dikendalikan sebagai sebuah bagian dari proses manajemen risiko.

Penelitian mengenai Critical Success Factor pada risk management sendiri belum banyak dilakukan Yaraghi \& Langhe (2011). Beberapa penelitian terkait dengan CSF Risk management diantaranya dilakukan oleh Oliveira, Méxas, Meiriño, \& Drumond (2018) dimana Oliviera et al mengidentifikasikan 10 critical success factor yang paling mempengaruhi penerapan enterprise risk management. Untuk sektor publik sendiri salah satu penelitian terkait dengan CSF Risk Management di publik sektor dilakukan oleh Boniface (2016). Dalam penelitian ini teridentifikasi ada 9 CSF Risk Management pada 
sektor publik. Dengan mengetahui CSF apa yang dibutuhkan dalam mengimplementasikan manajemen risiko, maka akan membantu organisasi untuk menciptakan kondisi yang diinginkan.

Hingga saat ini peneliti belum menemukan studi mengenai keberhasilan implementasi manajemen risiko sektor publik serta Critical Success Factor di Indonesia. Sehingga penelitian ini diharapkan dapat memberikan masukan mengenai Critical Success Factor apa yang diperlukan dalam mengimplementasikan manajemen risiko di sektor publik. Atas dasar hal tersebutlah maka penulis tertarik untuk melakukan penelitian terhadap Implementasi Manajemen Risiko di Kementerian Keuangan dan Critical Success Factor yang mempengaruhi keberhasilan tersebut.

Penelitian ini diharapkan dapat memberikan kontribusi terhadap perkembangan manajemen risiko serta dapat melengkapi pengetahuan mengenai manajemen risiko dengan melakukan studi dengan Critical Success Factor (CSF) dalam implementasi manajemen risiko di instansi pemerintah di Indonesia. Bagi Kementerian Keuangan selaku instansi pemerintah yang pertama kali menerapkan manajemen risiko, penelitian ini diharapkan dapat menujukkan area-area dari CSF mana yang dianggap kuat dan areaarea yang dianggap kurang sehingga dapat dilakukan perbaikan dalam penerapan manajemen risikonya.

Struktur dalam penelitian ini menjelaskan mengenai gambaran umum implementasi manajemen risiko di Kementerian Keuangan. Bagian selanjutnya menyajikan urain singkat mengenail literatur yang digunakan, serta konseptualisasi mengenai Critical Success Factor (CSF). Selanjutnya dibahas pula mengenai metodologi penelitian yang digunakan. Setelah membahas mengenai metodologi, selanjutnya disajikan hasil temuan dan pembahasannya. Pada bagian terakhir dibahas mengenai membahas rekomendasi yang dibuat dan kesimpulan, serta batasan dalam penelitian ini.

\section{TINJAUAN PUSTAKA}

\section{Teori agency}

Teori agensi dikembang oleh Jensen dan Meckling pada tahun 1976. Teori agensi menggambarkan hubungan antara principal dengan agen serta bagaimana pendelegasian atas kontrol. Ini menjelaskan cara terbaik untuk mengatur hubungan di mana satu pihak (pelaku) menentukan pekerjaan dan pihak mana (agen) melakukan atau membuat keputusan atas nama principal. Teori keagenan adalah teori manajemen dan ekonomi yang mencoba menjelaskan hubungan dan kepentingan pribadi dalam organisasi bisnis.

Menurut Jensen \& Meckling (1976) Teori agensi mewujudkan adanya kontrak agensi dimana terdapat hubungan antara pelaku (pemegang saham atau warga negara) dan agen (manajer), dan agen utama mengasumsikan peran pengambilan keputusan. Dalam instansi pemerintah terdapat pelimpahan wewenang dan tanggungjawab dimana warga negara yang diwakili oleh DPR memberikan wewenang kepada pemerintah untuk menjalankan roda organisasi kepemerintahan. Hal tersebut menjadi justifikasi bahwa terdapat hubungan keagenan dalam organisasi pemerintah di Indonesia.

Menurut Schroeck (2002) dengan menerapkan manajemen risiko bisa untuk menurunkan biaya keagenan serta meningkatkan nilai organisasi. Manajemen risiko juga dapat dijadian alat untuk pengawasan untuk menurunkan informasi asimetris serta berkontribusi dalam menghindari perilaku oportunis dari manajer.

\section{Manajemen risiko}

Definisi risiko yang diungkapkan dalam Monahan (2008), yaitu potensi kerugian yang disebabkan oleh sebuah kejadian (atau serangkaian kejadian) yang dapat 
berpengaruh terhadap pencapaian tujuan perusahaan. Berdasarkan ISO (2009) risiko di definisikan sebagai efek ketidakpastian pada tujuan organisasi, dimana akibat dari ketidakpastian ini dapat positif maupun negatif tergantung pada apa hasil yang diharapkan.

Berdasarkan ISO 31000 (2009) manajemen risiko didefinisikan sebagai serangkaian aktivitas dan metode yang terkoordinasi yang digunakan untuk mengarahkan organisasi, dan mengontrol banyak risiko yang dapat mempengaruhi kemampuan organisasi untuk mencapai tujuan. Tampubolon (2004) mendeskripsikan manajemen risiko sebagai suatu kegiatan atau proses yang terarah serta bersifat proaktif, yang ditujukan untuk mengakomodasi kemungkinan gagal pada salah satu, atau sebagian dari sebuat transaksi atau instrument. Anderson \& Terp (2006) menyatakan bahwa pada dasarnya, manajemen risiko dapat didefinisikan sebagai suatu proses untuk menghilangkan, mengurangi dan mengendalikan risiko, meningkatkan manfaat, dan menghindari kerugian dari paparan spekulatif. Sehingga dari berbagai definisi tersebut dapat disimpulkan bahwa manajemen risiko merupakan aktifitas dan metode yang digunakan organisasi untuk mengendalikan risiko yang dapat mempengaruhi kemampuan organisasi dalam pencapaian tujuan.

\section{Critical success factor}

Konsep mengenai “Critical Success Factor" telah berkembang sejak lama, konsep pertama dimulai ketika D. Ronald Daniel dari McKinsey \& Company pada tahun 1961 memperkenalkan "Success Factor". D. Ronald Daniel menyatakan bahwa dalam perusahaan, sistem informasi perusahaan harus diskriminatif dan selektif. Sistem tersebut harus fokus pada 'faktor kesuksesan'. Di sebagian besar industri biasanya ada tiga hingga enam faktor yang menentukan keberhasilan; pekerjaan utama ini harus dilakukan dengan sangat baik agar perusahaan dapat berhasil (Rockart, 1979).

Penelitian dengan menggunakan studi literatur dilakukan untuk menentukan CSF yang akan digunakan. Dari hasil penelitian tersebut maka dapat dikumpulkan faktor yang mendukung keberhasilan implementasi manajemen risiko. CSF yang pertama diidentifikasi adalah Risk Management Knowledge (Oliveira, Méxas, Meiriño, \& Drumond, 2018), (Yaraghi \& Langhe, 2011), (Na Ranong \& Phuenngam, 2009), (Boniface, 2016), (Braig, Gebre, \& Sellgren, 2011), (Chileshe \& Kikwasi, 2014), (Ahmed \& Manab, 2016), (Zhao, Hwang, \& Low, 2013). Dalam faktor ini yang menjadi fokus perhatian adalah bagaimana entitas di dalam Kementerian Keuangan mendapatkan pengetahuan mengenai manajemen risiko, serta hal-hal yang dianggap penting dalam memperoleh pengetahuan tersebut. CSF yang kedua adalah Management Commitment \& Leadership (Oliveira, Méxas, Meiriño, \& Drumond, 2018), (Yaraghi \& Langhe, 2011), (Na Ranong \& Phuenngam, 2009), (Boniface, 2016), (Braig, Gebre, \& Sellgren, 2011), (Chileshe \& Kikwasi, 2014), (Ahmed \& Manab, 2016), (Zhao, Hwang, \& Low, 2013), (Gottwald \& Mensah, 2015). Dalam faktor ini dicari informasi mengenai bagaimana komitmen manajemen pimpinan dalam mengimplementasikan manajemen risiko, strategi apa yang dilakukan agar manajemen risiko tersebut dapat terlaksana dengan baik.

CSF selanjutnya adalah Culture (Oliveira, Méxas, Meiriño, \& Drumond, 2018), (Yaraghi \& Langhe, 2011), (Na Ranong \& Phuenngam, 2009), (Boniface, 2016), (Chileshe \& Kikwasi, 2014), (Ahmed \& Manab, 2016), (Zhao, Hwang, \& Low, 2013). Dalam faktor ini digali informasi mengenai bagaimana nilai serta kebiasaan yang ada di Kementerian Keuangan saat diterapkannya manajemen risiko. CSF yang ke empat adalah Organizational Structure (Oliveira, Méxas, Meiriño, \& Drumond, 2018), (Yaraghi \& Langhe, 2011), (Na Ranong \& Phuenngam, 2009), (Boniface, 2016), (Braig, Gebre, \& Sellgren, 2011), (Chileshe \& Kikwasi, 2014), (Ahmed \& Manab, 2016), (Zhao, Hwang, 
\& Low, 2013), (Gottwald \& Mensah, 2015), yang menjadi fokus dalam faktor ini adalah perlu atau tidak struktur organisasi tersendiri yang menangani terkait manajemen risiko.

CSF selanjutnya yang teridentifikasi adalah Risk Monitoring \& Evaluation (Oliveira, Méxas, Meiriño, \& Drumond, 2018), (Boniface, 2016), (Braig, Gebre, \& Sellgren, 2011), (Ahmed \& Manab, 2016), (Zhao, Hwang, \& Low, 2013). Dalam faktor ini dicari informasi mengenai bagaimana proses pemantauan terhadap manajemen risiko, serta evaluasi seperti apa yang dilakukan setelah risiko yang diidentifikasi. CSF selanjutnya adalah Documentation \& Reporting (Yaraghi \& Langhe, 2011). Dalam faktor ini akan dilihat bagaimana peranan proses pendokumentasian manajemen risiko serta bagaimana proses pelaporannya untuk menunjang keberhasilan manajemen risiko.

CSF yang ke tujuh adalah External Environment (Yaraghi \& Langhe, 2011), (Braig, Gebre, \& Sellgren, 2011), (Chileshe \& Kikwasi, 2014). Dalam faktor ini bagaimana lingkungan di luar Kementerian Keuangan mempengaruhi penerapan manajemen risiko, apakah ada instansi lain yang menyebabkan Kementarian Keuangan menerapkan manajemen risiko. CSF terakhir yang teridentifikasi adalah Consultant (Yaraghi \& Langhe, 2011), (Chileshe \& Kikwasi, 2014). Dalam faktor ini akan dilihat apakah terdapat peran konsultan dalam implementasi manajemen risiko di lingkungan Kementerian Keuangan.

\section{METODE}

Disesuaikan dengan permasalahan yang diteliti, maka metode yang digunakan dalam penyusunan karya ilmiah ini ialah metode penelitian kualitatif dengan pendekatan studi kasus. Penelitian kualitatif dengan pendekatan studi kasus memberikan kesempatan pada peneliti untuk menyelidiki dan memahami lebih dalam tentang seluk-beluk fenomena yang kompleks, khususnya dalam mendapatkan perspektif dari individu dalam organisasi (Flick 2007, 2019); (Denzin \& Lincoln, 2017).

Studi kasus dilakukan pada Kementerian Keuangan. Pemilihan Kementerian Keuangan dikarenakan pada instansi tersebut semenjak tahun 2008 sudah diimplementasikan manajemen risiko. Dalam melihat implementasi manajemen risiko di Kementerian Keuangan dimulai dari apa yang menyebabkan Kementerian Keuangan menerapkan manajemen risiko hingga perkembangan terkini manajemen risiko di Kementerian Keuangan. Penelitian ini pula melihat apa yang menjadi Critical Success Factor manajemen risiko di kementerian keuangan. Faktor-faktor tersebut akan dilihat dari aspek persiapan implementasi manajemen risiko serta aspek saat implementasi sehingga dapat diketahui faktor-faktor tersebut berkontribusi saat masa awal manajemen risiko atau saat manajemen risiko tersebut sudah berjalan.

Penelitian ini menggunakan teknik pengumpulan data dengan melakukan penelitian lapangan dan penelitian kepustakaan. Dalam mengumpulkan data tersebut dilakukan dengan cara melkukan wawancara secara langsung dengan bentuk semi-structured interviews. Wawancara tersebut dilakukan kepada 3 narasumber di lingkungan Kementerian Keuangan yang dianggap cukup mumpuni untuk memberikan informasi yang dibutuhkan. Dengan responden terdiri dari 2 orang auditor madya di Inspektorat Jenderal dan 1 orang tenaga Analisis Pengelolaan Kinerja dan Risiko Bagian Pengelolaan Kinerja dan Risiko, Biro Perencanaan dan Keuangan Sekertariat Jenderal. Hal tersebut pun sebagai bentuk triangulasi dimana pendapat antar narasumber dapat sebagai penguat atas pendapat yang lain. Analisis data yang dilakukan menggunakan model miles \& Huberman, dimana seluruh data dikumpulkan untuk kemudian dilakukan reduksi data, serta penyajian data selanjutnya adalah penarikan kesimpulan. Dalam hal ini data yang dikumpulkan berupa data hasil wawancara serta dokumen pendukung sebagai triangulasi 
hasil wawancara tersebut. Data pendukung tersebut berupa peraturan-peraturan serta laporan kinerja Kementerian Keuangan.

\section{HASIL DAN PEMBAHASAN}

\section{Implementasi manajemen risiko di kementerian keuangan}

Semenjak era reformasi di tahun 1998 tuntutan terhadap kinerja organisasi sektor publik pun semakin meningkat. Keinginan untuk melihat kinerja instansi pemerintah yang transparan, serta adanya tuntutan terhadap akuntabilitas atas setiap tindakantindakan yang dilakukan oleh organisasi sektor publik tersebut menjadi sebuah keniscayaan ( (Wicaksono, 2015); (Randa \& Tangke, 2015)). Guna mewujudkan hal tersebut, serta untuk memperbaiki kinerjanya maka Kementerian Keuangan menerapkan suatu manajemen kinerja dengan menerapkan Balanced Scorecard (Soebroto, 2010). Penerapan manajemen kinerja tersebutlah yang kemudian mendorong Kementerian Keuangan untuk juga menerapkan manajemen risiko sebagai salah satu upaya untuk membantu kementerian keuangan dalam mencapai tujuan yang sudah dipetakan dalam Balanced Scorecard. Dengan diterapkannya Manajemen Risiko tersebut maka Kementerian Keuangan menjadi instansi pemerintah pertama yang menerapkannya. Hal ini ditandai dengan terbitnya Peraturan Menteri Keuangan Nomor. 191/PMK.09/2008 tentang Penerapan Manajemen Risiko di Lingkungan Departemen Keuangan. Sebagai pionir dalam implementasi manajemen risiko tersebut menyebabkan Kementerian Keuangan mengalami kesulitan untuk menemukan best practise manajemen risiko di sektor publik di indonesia. Untuk mengatasi hal tersebut maka dalam menyusun panduan mengenai Manajemen Risiko dilakukan dengan menggabungkan berbagai framework manajemen risiko yang ada, diantaranya ISO31000, COSO, ANZ 2004, Orange Book, dan lain sebagainya.

Diawal periode ini tidak selamanya manajemen risiko berjalan dengan baik, banyak kendala yang dihadapi ketika akan mengimplementasikannya. Kendala yang paling dirasakan adalah dari sumber daya manusia nya. Kendala tersebut berupa masih rendahnya awareness atau kesadaran terhadap manajemen risiko. Hal tersebut dirasakan sebagai beban yang memberatkan bagi para pegawainya. Sebagaimana yang disampaikan oleh narasumber "ya awareness, orang belum ngerti apa manajemen risiko kendalanya disitu awareness."

Masalah-masalah tersebut dapat diatasi dengan adanya komitmen dari pimpinan serta adanya training, pelatihan dan sosialisasi. Dengan adanya komitmen dari pimpinan maka akan ada dorongan dari atas untuk memaksakan sesuatu yang baru agar dapat diterima oleh para pegawai di bawahnya. Begitu pun dengan training, pelatihan dan sosialisasi yang dilakukan secara terus menerus sehingga dapat membangun kesadaran tersebut, dan diperlukan adanya dukungan anggaran yang tidak sedikit serta waktu yang lama untuk membentuk kesadaran tersebut.

"Ada macam2, pertama ada diklat, ada diklat manajemen risiko dilakukan oleh badan pendidikan. Yang kedua dilakukan sosialisasi dilakukan terus menerus, ada lagi yang dikirim bagi yang berminat untuk melakukan course di berbagai tempat supaya apabila ada yang mendapat ilmu baru menjadi bagian dari itu"

Manajemen risiko sendiri merupakan alat bagi manajemen, sehingga dapat memberikan pertimbangan kepada perusahaan secara terstruktur dengan memperhatikan segala bentuk ketidakpastian dalam pengambilan keputusan dan tindakan yang harus diambil guna menangani risiko (Anggraini \& Pertiwi, 2017). Oleh karena itu pada tahun 2016 pula terjadi perubahan dalam pengelolaan manajemen risiko di Kementerian Keuangan, jika sebelumnya manajemen risiko dikelola oleh Inspektorat Jenderal 
Kementerian keuangan maka di tahun 2016 tersebut pengelolaan manajemen risiko diserahkan ke Biro Perencanaan dan Keuangan Sekretariat Jenderal Kementerian Keuangan di bagian pengelolaan kinerja dan risiko.

Tabel 2. Perkembangan manajemen risiko di kementerian keuangan Periode 2008-2015

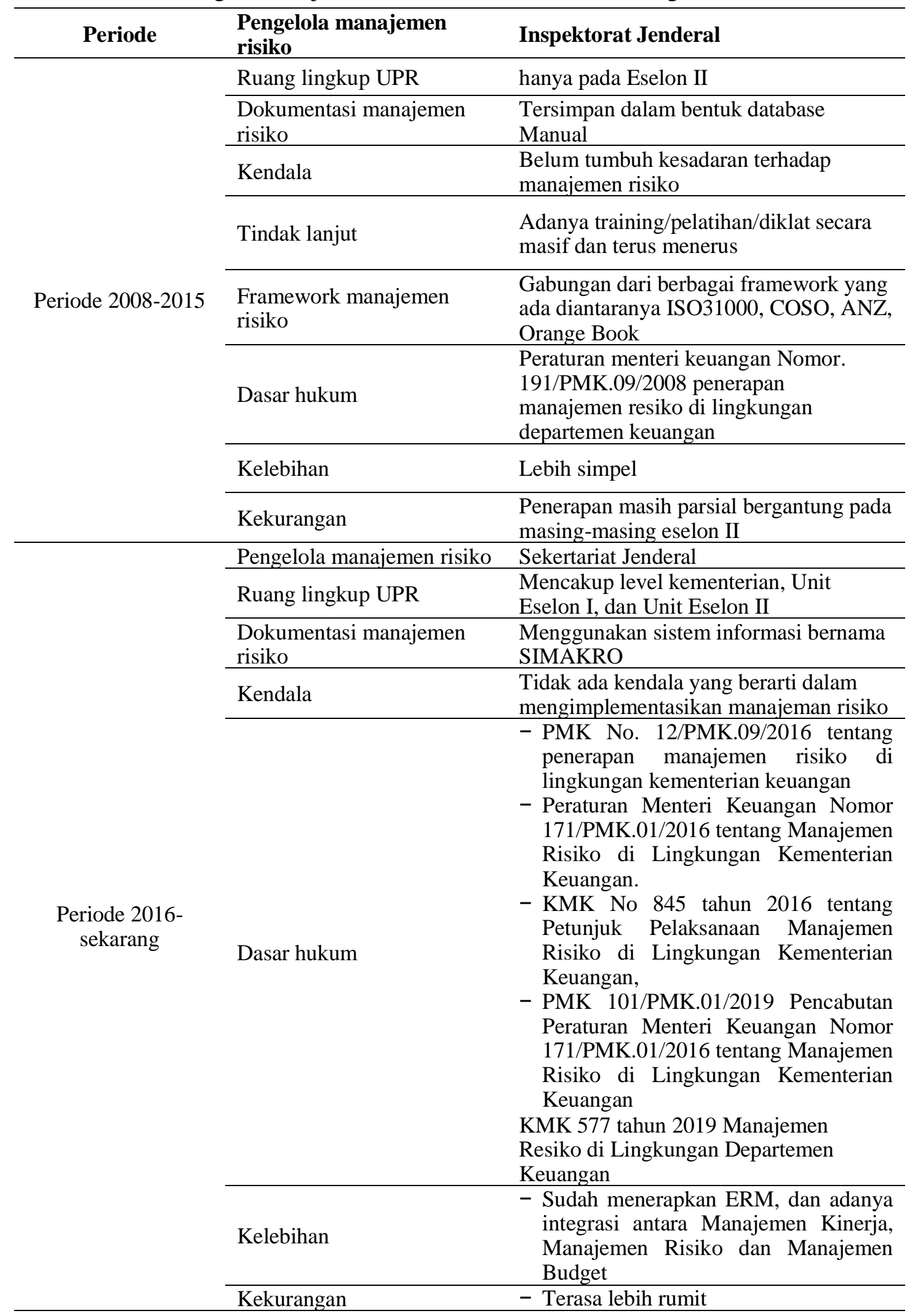


Berdasarkan hasil wawancara, kondisi existing saat ini terdapat 4 macam implementasi manajemen risiko. "Implementasi RM di Kemenkeu pun dibagi menjadi beberapa implementasi yaitu: Implementasi Struktur RM, Implementasi Budaya RM, Implementasi Proses RM, Implementasi Sistem Pendukung RM".

Berdasarkan hasil wawancara, kondisi existing saat ini terdapat 4 macam implementasi manajemen risiko. "Implementasi RM di Kemenkeu pun dibagi menjadi beberapa implementasi yaitu: Implementasi Struktur RM, Implementasi Budaya RM, Implementasi Proses RM, Implementasi Sistem Pendukung RM"

Ke empat macam implementasi manajemen risiko tersebut adalah:

\section{Implementasi struktur manajemen risiko}

Keputusan Menteri Keuangan nomor 577/KMK.01/2019 telah mengakomodir perubahan dari ISO maupun COSO, hal ini menyebabkan Kementerian Keuangan telah mengadopsi ERM secara utuh. Secara struktur manajemen risiko di Kememkeu dibagi menjadi 3 yaitu UPR (Unit Pemilik Risiko), Unit Kepatuhan Risiko dan Itjen sebagai reviewer. UPR ini dibentuk dari level paling tinggi ke yang paling rendah, yang dikenal dengan istilah Kemenkeu wide, Kemenkeu one, Kemenekeu two, Kemenekeu three, Kemenekeu Four, kemenkeu five. Hal ini mencerminkan fungsi-fungsi unit organisasi, jika kemenkeu wide setara menteri, Kemenkeu one setara Eselon 1, Kemenkeu two setara setara eselon 2, kemenkeu three setara eselon 3, kemenkeu four setara eselon 4, kemenkeu five setara pelaksana. Tetapi untuk manajemen risiko hanya untuk sampai dengan kemenkeu three.

\section{Implementasi budaya manajemen risiko}

Suatu sistem baru dapat berjalan dengan baik hanya terjadi apabila di budaya dalam entitas tersebut dapat menerimanya. Implementasi budaya manajemen risiko dibagi menjadi 4 unsur yaitu: komitmen pimpinan, manajemen resiko dalam proses bisnis, manajemen risiko dalam pengambilan keputusan, dan Penghargaan atau reward.

\section{Komitmen pimpinan.}

Komitmen pimpinan merupakan hal yang terpenting dalam budaya manajemen risiko, tanpa adanya komitmen dari pimpinan maka sistem tersebut tidak akan jalan.

\section{Implementasi manajemen risiko dalam proses bisnis kementerian keuangan.}

Dengan mengintegrasikan manajemen risiko dalam proses bisnis Kementerian Keuangan maka yang diharapkan adalah manajemen risiko dapat membantu Kementerian Keuangan dalam mencapai tujuan strategis nya.

\section{Penggunaan manajemen risiko dalam pengambilan keputusan.}

Dengan menggunakan manajemen risiko dalam pengambilan keputusan maka diharapkan menghasilkan keputusan yang terbaik. Dalam hal ini sebelum mengambil keputusan harus sudah diidentifikasi terlebih dahulu potensi risiko-risiko yang terjadi, sehingga keputusan yang diambil pun merupakan keputusan yang terbaik.

\section{Penghargaan atau reward.}

Pemberian reward atau penghargaan menjadi salah satu unsur budaya manajemen risiko di Kementerian Keuangan. Tentunya hal ini bermaksud agar setiap risiko yang telah teridentifikasi dapat dikendalikan dengan baik.

\section{Implementasi proses manajemen risiko}

KMK 577/KMK.01/2019 menyatakan bahwa proses manajemen risiko ada beberapa tahapan, yaitu sebagai berikut: 


\section{Communication and consultation.}

Dalam proses komunikasi dan konsultasi dilakukan dalam bentuk:1).Rapat berkala, 2).Rapat incidental, 3).Diskusi kelompok terarah (Focused group discussion)

\section{Establishing the context.}

Proses perumusan konteks dilakukan dengan beberapa tahap yaitu: $a$ ). Menentukan ruang lingkup dan periode penerapan manajemen risiko, b).Menentukan sasaran organisasi, $c$ ). Mengidentifikasi pemangku kepentingan, $d$ ). Menentukan struktur Unit Pemilik Risiko (UPR), e).Menuangkan hasil perumusan konteks dalam formulir konteks manajemen risiko

Dalam pelaksanaannya seluruh tahapan ini dilakukan pada akhir tahun bulan November sampai dengan bulan Januari tahun berikutnya.

\section{Risk Identification}

Dalam melakukan identifikasi risiko memiliki tujuan untuk mengetahui risikorisiko yang akan mempengaruhi capaian sasaran organisasi. Proses identifikasi risiko dilakukan selama bulan November s/d Januari tahun berikutnya.

\section{Risk Analysis}

Risk Analysis bertujuan untuk menentukan besaran risiko dan level risiko.

\section{Risk evaluation}

Risk evaluation memiliki tujuan untuk menentukan prioritas risiko, besaran/level risiko residual harapan, keputusan mitigasi risiko dan indikator risiko utama.

\section{Risk mitigation}

Mitigasi risiko merupakan tindakan yang bertujuan untuk menurunkan, menjaga risiko hingga mencapai Risiko Risidual Harapan. Hal ini dilakukan dengan cara mengidentifikasi dan memilih mitigasi risiko, menyusun rencana mitigasi, dan melaksanakan rencana mitigasi tersebut.

\section{Monitoring and review}

Tahapan ini bertujuan untuk memastikan bahwa manajemen risiko yang berjalan sudah berjalan dengan efektif sesuai dengan rencana dan memberikan umpan balik bagi proses penyempurnaan manajemen risiko.

\section{Implementasi sistem pendukung manajemen risiko}

Sistem pendukung manajemen risiko di sini merupakan salah satu upaya dari pihak Kementerian Keuangan agar sistem manajemen risiko yang telah dibangun bisa dimanfaatkan sebaik mungkin. Selain itu dengan adanya sistem pendukung ini akan membantu dalam proses pendokumentasian manajemen risiko tersebut.

Dalam melaksanakan manajemen risiko, seluruh proses merupakan merupakan bagian yang terpadu dengan proses manajemen secara keseluruhan, khususnya dengan perencanaan strategis, penganggaran, kinerja, dan sistem pengendalian internal, serta menyatu dalam budaya dan proses bisnis organisasi. Karena sifatnya yang melekat tersebut sehingga tidak ditemukan program khusus mengenai implementasi manajemen risiko. Sedangkan untuk mengukur keberhasilan kinerja manajemen risiko dilakukan berdasarkan asesmen kematangan implementasi manajemen risiko oleh Risk Workshop International (RWI) Indonesia, dimana untuk tahun 2019 diperoleh nilai 88,24\% (Tingkat 5) dengan predikat optimized - middle yang merupakan tingkat maturitas level tertinggi (Kementerian Keuangan Republik Indonesia, 2019). 


\section{Critical success factor}

Hasil wawancara menunjukkan bahwa Management Commitment \& Leadership merupakan critical success factor yang paling utama. Dalam CSF ini ditanyakan mengenai peranan pimpinan serta bagaimana bentuk komitmen dari pimpinan tersebut. Dari hasil wawancara tersebut diketahui bahwa ternyata pimpinan merupakan faktor yang paling penting dalam penerapan manajemen risiko. Selain itu diperlukan adanya IKU (Indikator Kinerja Utama) terkait manajemen risiko sebagai bentuk komitmen pimpinan. Hal ini sejalan dengan apa yang disampaikan oleh Na Ranong \& Phuenngam (2009) dimana diperlukan dukungan dan komitmen dari jajaran manajemen terhadap implementasi manajemen risiko.

Selanjutnya adalah Risk Management Knowledge. Dalam CSF ini ditanyakan mengenai bagaimana Kementerian keuangan melakukan proses pendidikan dan pelatihan dalam upaya menumbuhkan pengetahuan tentang manajemen risiko bagi entitas di organisasi. Pengetahuan mengenai manajemen risiko sangat penting karena pengetahuan yang mumpuni terhadap manajemen risiko dapat membantu organisasi untuk mengidentifikasi, menganalisis, dan mengembangkan respons terhadap paparan risiko, sehingga dapat ditentukan tindakan yang tepat untuk untuk mengantisipasi risiko tersebut. Dengan cara menentukan prioritas untuk menyusun respons untuk mengurangi probabilitas kejadian dan/atau dampak dari peristiwa tersebut Oliveira, Méxas, Meiriño, \& Drumond (2018). Hasil wawancara menyatakan bahwa pendidikan dan pelatihan untuk meningkatkan pengetahuan tentang manajemen risiko memang dilakukan dan diperuntukkan seluruh pegawai Kementerian Keuangan.

Faktor selanjutnya adalah Organizational Structure, Dalam CSF ini ditanyakan mengenai struktur organisasi yang diperlukan apabila ingin menerapkan manajemen risiko. Hasil wawancara menyatakan bahwa diperlukan suatu struktur organisasi tersendiri yang khusus menangani mengenai manajemen risiko. Hal ini diperlukan karena dalam mengelola manajemen risiko diperlukan orang-orang yang fokus untuk menjalankan manajemen risiko agar tidak terganggu oleh hal-hal lain. Hal ini sejalan dengan apa yang disampaikan oleh (Banham, 2004) bagi organisasi, sangat penting untuk memiliki orang yang bertangungjawab untuk mengelola dan mengawasi risiko.

Faktor selanjutnya Risk Monitoring \& Evaluation. Dalam CSF ini ditanyakan mengenai bagaimana bentuk monitoring risiko dan bagaimana evaluasi risiko dilakukan. Untuk menghasilkan suatu manajemen risiko yang efektif dan efisien, maka diperlukan proses manajemen risiko yang berkesinambungan. Hal ini dapat diperoleh melalui proses monitoring dan evaluasi atas manajemen risiko yang telah dilakukan dengan cara melakukan verifikasi, terhadap proses, kebijakan dan prosedur manajemen risiko (Oliveira, Méxas, Meiriño, \& Drumond, 2018). Dari hasil wawancara diperoleh informasi bahwa risk monitoring \& evaluation dilakukan secara rutin dan berkala.

Faktor selanjutnya adalah Culture, Dalam CSF ini ditanyakan mengenai bentuk dari budaya manajemen risiko. Budaya merupakan efek dari kebiasaan, dimana dari hasil wawancara diketahui bahwa saat ini manajemen risiko telah menjadi budaya dalam proses bisnis Kementerian Keuangan sebagai contoh adanya kode etik yang harus dipatuhi oleh seluruh pegawai. Menurut (Kikwasi, 2018) merupakan kebiasaan yang terus menerus dilakukan secara berulang dalam organisasi sehingga menghasilkan sesuatu ide, pengetahuan, atau solusi dari suatu masalah.

Faktor selanjutnya adalah Documentation \& Reporting. Dalam CSF ini ditanyakan mengenai bagaimana proses terhadap dokumentasi dan pelaporan manajemen risiko. Dokumentasi dan laporan ini disimpan dengan baik meskipun penggunaan sistem 
informasi (SIMAKRO) untuk dokumentasi dan pelaporan baru dikembangkan. Faktor ini dapat dikatakan merupakan faktor pendukung dari implementasi manajemen risiko, meskipun juga memiliki peran yang cukup penting. Menurut (Yaraghi \& Langhe, 2011) dokumentasi merupakan sebuah sistem dokumentasi yang digunakan dalam organisasi, beserta infrastruktur perangkat keras dan kemampuan perangkat lunaknya. Ini juga termasuk tingkat akurasi data dalam organisasi selain itu. Selain itu diperlukan pula pelaporan terhadap kinerja baik dalam jangka pendek atau jangka panjang untuk menilai apakah manajemen risiko telah berjalan sebagaimana mestinya.

Tabel 3. Hasil wawancara critical success factor

\begin{tabular}{|c|c|c|}
\hline No. & CSF & Point Penting Hasil Wawancara \\
\hline 1 & $\begin{array}{l}\text { Risk Management } \\
\text { Knowledge }\end{array}$ & Perlu adanya pendidikan dan pelatihan secara masif. \\
\hline 2 & $\begin{array}{l}\text { Management } \\
\text { Commitment \& } \\
\text { Leadership }\end{array}$ & Komitmen pimpinan merupakan hal terpenting. \\
\hline 3 & Culture & $\begin{array}{l}\text { Akan terbentuk setelah manajemen risiko menjadi } \\
\text { kebiasaan. }\end{array}$ \\
\hline 4 & $\begin{array}{l}\text { Organizational } \\
\text { Structure }\end{array}$ & $\begin{array}{l}\text { Diperlukan struktur organisasi tersendiri yang } \\
\text { khusus menangani manajemen risiko }\end{array}$ \\
\hline 5 & $\begin{array}{l}\text { Risk Monitoring } \\
\text { \& Evaluation }\end{array}$ & $\begin{array}{l}\text { Dilakukan secara berkala, dan dipimpin langsung } \\
\text { oleh pimpinan Kementerian Keuangan }\end{array}$ \\
\hline 6 & $\begin{array}{l}\text { Documentation \& } \\
\text { Reporting }\end{array}$ & $\begin{array}{l}\text { Dokumentasi dan Pelaporan manajemen risiko } \\
\text { tersimpan dengan baik, meskipun penggunaan sistem } \\
\text { informasi SIMAKRO sedang dalam pengembangan. }\end{array}$ \\
\hline 7 & $\begin{array}{l}\text { External } \\
\text { Environment }\end{array}$ & $\begin{array}{l}\text { Tidak ada instansi di luar Kementerian Keuangan } \\
\text { yang lebih dulu menerapkan manajemen risiko. }\end{array}$ \\
\hline 8 & Consultant & $\begin{array}{l}\text { Konsultan sempat digunakan di awal proses } \\
\text { implementasi manajemen risiko, penggunaan } \\
\text { konsultan hanya untuk memberikan masukan agar } \\
\text { apa yang dilakukan tidak melenceng jauh dari } \\
\text { keilmuannya. }\end{array}$ \\
\hline
\end{tabular}

Sumber: Data diolah, 2021

Faktor selanjutnya adalah External Environment, dalam CSF ini ditanyakan mengenai bagaimana lingkungan di luar instansi dapat memberikan pengaruh dalam implementasi manajemen risiko. Hal ini seperti apa yang diungkapkan oleh (Yaraghi \& Langhe, 2011) dimana lingkungan luar merupakan segala entitas diluar lingkungan organisasi yang menyebabkan organsisasi tersebut bereaksi. Dapat berupa sistem sosial politik, pesaing, kondisi perekonomian. Dari hasil wawancara diperoleh hasil bahwa Kementerian Keuangan sebagai instansi pemerintah yang pertama kali menerapkan manajemen risiko, sehingga dalam menerapkan manajemen risiko tersebut kementerian keuangan sering kali kesulitan menemukan rujukan untuk implementasi manajemen risiko tersebut. Oleh karena itu ketika menyusun panduan terkait manajemen risiko yang dilakukan adalah mengumpulkan berbagai macam framework untuk kemudian di mixing menjadi satu aturan manajemen risiko yang dirasa cocok untuk Kementerian Keuangan.

Terakhir adalah faktor Consultant, dalam CSF ini ditanyakan mengenai apakah ada konsultan luar yang terlibat dalam pelaksanaan manajemen risiko di kementerian keuangan. Keberadaan konsultan manajemen risiko dapat mempengaruhi pelaksanaan manajemen risiko yang efektif. Karena konsultan disini memberikan masukan atas pelaksanaan manajemen risiko (Chileshe \& Kikwasi, 2014). Dari hasil wawancara didapat informasi bahwa konsultan tidak terlalu berperan. Proses pembelajaran dan 
implementasi dilakukan secara mandiri dengan mempelajari dari berbagai framework yang ada. Meskipun demikian konsultan sempat digunakan di awal proses mengimplementasikan manajemen risiko. Penggunaan konsultan hanya untuk memberikan masukan agar apa yang dilakukan oleh kementerian keuangan tidak menyimpang jauh jadi keilmuannya.

\section{Simpulan}

Implementasi manajemen risiko di Kementerian Keuangan telah berjalan kurang lebih selama 12 tahun sejak dikeluarkannya Peraturan Menteri Keuangan nomor 191/PMK.09/2008. Selama itu pula berbagai perubahan peraturan terjadi hingga ditetapkannya Keputusan Menteri Keuangan nomor 577/KMK.01/2019. Pelaksanaan manajemen risiko di Kementerian Keuangan pun merupakan salah satu best practise implementasi manajemen risiko di instansi pemerintah. Tidak heran apabila banyak kementerian atau instansi lain yang melakukan benchmarking penerapan manajemen risiko di Kementerian Keuangan. Dalam perjalanannya juga terjadi perpindahan pengelolaan manajemen risiko dari Inspektorat Jenderal ke Sekertariat Jenderal Kementerian Keuangan. Perpindahan ini terjadi karena manajemen risiko merupakan alat bagi manajemen untuk mencapai tujuan.

Penelitian ini diharapkan dapat menjadi masukan dan pertimbangan bagi instansi pemerintah agar dapat menerapkan manajemen risiko. Karena dengan menerapkan manajemen risiko maka dapat membantu instansi tersebut agar tercapai tujuannya. Berdasarkan hasil wawancara pula, penulis berpendapat bahwa Critical Success Factor dapat dikelompokkan menjadi 2 kelompok dalam mengimplementasikan manajemen risiko. Kelompok tersebut adalah:

Critical Success Factor manajemen risiko di awal implementasi

Adapun CSF yang dapat masuk dalam kelompok ini adalah: a).Management Commitment \& Leadership, b).Risk Management Knowledge, c).External Environment, d).Consultant. Critical Success Factor manajemen risiko setelah implementasi yang terdiri dari: a).Organizational structure, c). Risk monitoring \& evaluation, d).Culture, e).Documentation \& reporting

Penelitian ini dilakukan pada masa pandemi Covid-19 sehingga banyak keterbatasan-keterbatasan yang penulis alami. Untuk penelitian selanjutnya selain dilakukan dengan metode wawancara proses pengumpulan data dapat dilakukan dengan melakukan observasi langsung terhadap proses manajemen risiko, sehingga akan didapat kedalaman informasi mengenai praktik manajemen risiko di Kementerian Keuangan. Bagi Kementerian Keuangan sendiri penelitian ini diharapkan dapat memberikan masukan perbaikan untuk implementasi manajemen risiko itu sendiri.

\section{DAFTAR PUSTAKA}

Ahmed, I., \& Manab, N. A. (2016). Influence of enterprise risk management success factors on firm financial and non-financial performance: a proposed model . International Journal of Economics and Financial Issues 6(3), 830-836.

Anderson, K., \& Terp, A. (2006). Perspectives on strategic risk management . Copenhagen Bussiness School Press: Copenhagen

Anggraini, \& Pertiwi, I. D. (2017). Analisa pengelolaan risiko penerapan teknologi informasi menggunankan ISO 31000. Jurnal Ilmiah Rekayasa dan Manajemen Sistem Informasi 3(2), 70-76.

Banham, R. (2004). Enterprising views of risk management. Journal of Accountancy 197(6), 65-72.

Boniface, O. (2016). Financial risks management in public sector organisations . Research Journal of Finance and Accounting 7(1), 94-106. 
Braig, S., Gebre, B., \& Sellgren, A. (2011). Strengthening risk management in the US public sector. McKinsey \& Company: Washington DC

Chileshe, N., \& Kikwasi, J. G. (2014). Critical success factors for implementation of risk assessment and management practices within the Tanzanian construction industry. Engineering, Construction and Architectural Management 21(3), 291-319.

Denzin, N. K., \& Lincoln, Y. S. (2017). The SAGE handbook of qualitative research. SAGE Publication Inc: New Jersey

Flick, U. (2007). Managing quality in qualitative research. SAGE Publication Inc: New Jersey

Flick, U. (2019). The concepts of qualitative data: challenges in neoliberal times for qualitative inquiry. Qualitative Inquiry 25(8), 713-720.

Florio, C., \& Leoni, G. (2017). Enterprise risk management and firm performance: The Italian case. The British Accounting Review 49, 56-74.

Gottwald, W. D., \& Mensah, G. K. (2015). Enterprise risk management: factors associated with effective implementation. Available at SSRN: https://ssrn.com/abstract $=2735096$.

International Standard ISO 31000. (2009). Risk managemen -principle and guideline.

Jensen, M. C., \& Meckling, W. H. (1976). Theory of the firm: managerial behavior, agency cost and ownership structure. Journal of Financial Economics 3(4), 305360.

Kapuscinska, K., \& Matejun, M. (2014). Risk management in publict sector organization: a case study. International Journal of Business and Management Studies 3 (3), 129-143.

Kementerian Keuangan Republik Indonesia. (2016). Laporan kinerja kementerian keuangan 2016. Kementerian Keuangan Republik Indonesia: Jakarta

Kementerian Keuangan Republik Indonesia. (2017). Laporan kinerja kementerian keuangan 2017. Kementerian Keuangan Republik Indonesia: Jakarta

Kementerian Keuangan Republik Indonesia. (2018). Laporan kinerja kementerian keuangan 2018. Kementerian Keuangan Republik Indonesia: Jakarta

Kementerian Keuangan Republik Indonesia. (2019). Laporan kinerja kementerian keuangan 2019. Kementerian Keuangan: Jakarta

Kikwasi, G. J. (2018). Critical success factors for effective risk management. In C. Oduoza, Risk Management Treatise for Engineering Practitioners IntechOpen: London. Hal, 73-94

Lark, J. (2015). ISO 31000: Risk management - A practical guide for SMEs. Switzerland: ISO.

Leung, F., \& Isaacs, F. (2008). Risk management in public sector research: Approach and lessons learned at a national research organization. $R$ and $D$ Mnagement 38 (5), 510-519.

Monahan, G. (2008). Enterprise risk management: a methodology for achieving strategic objectives. John Wiley \& Sons, Inc: Hoboken

Na Ranong, P., \& Phuenngam, W. (2009). Critical success factors for effective risk management procedures in financial industries. Umea University: Thailand

Oliveira, K., Méxas, M., Meiriño, M., \& Drumond, G. (2018). Critical success factors associated with the implementation of enterprise risk management. Journal of Risk Research, 22(6), 1-16.

Randa, F., \& Tangke, P. (2015). Developing accountability model of local government organization: from managerial accountability to public accountability (naturalistic study on local government Tana Toraja). 2nd Global Conference on Business and Social Science, 211 (2015),665 - 672).

Rockart, J. F. (1979, March). Chief executives define their own data needs. Sussex Business Review. 
Schneider, G. P., Sheikh, a., \& Simione, K. (2012). Holistic risk management: An expanded role for internal auditors. Academy of Accounting and Financial Studies Journal 16 (1), 25-34.

Schroeck, G. (2002). Risk management and value creation in financial institutions. John Wiley \& Sons, Inc: Hoboken

Soebroto, S. (2010). Evaluasi atas penerapan balanced scorecard pada inspektorat jenderal kementerian keuangan. Master Thesis, Universitas Indonesia: Depok.

Tampubolon, R. (2004). Manajemen risiko: Pendekatyan Kualitatif. PT Elex Media Komputindo, Jakarta

Wicaksono, K. W. (2015). Akuntabilitas organisasi sektor publik . Jurnal Kebijakan \& Administrasi Publik 19(1), 3-15.

Yaraghi, N., \& Langhe, R. G. (2011). Critical success factors for risk. Journal of Risk Research 14(5), 551-581.

Zhao, X., Hwang, B.-G., \& Low, S. P. (2013). Critical success factors for enterprise risk management in Chinese construction companies. Construction Management and Economics 31(12), 1199-1214. 